\title{
Green infrastructure-based hydrological modelling, a comparison between different urban districts, through the case of Szeged, Hungary
}

\author{
Áкos Kristóf CSETE ${ }^{1}$ and Ágnes GULY ÁS
}

\begin{abstract}
Because of the climate uncertainties caused by climate change and the growing urban areas, today's cities face new environmental challenges. The impervious artificial elements change the urban water cycle. Urban districts with inadequate water infrastructure and treatment can be a major source of environmental risks, like urban flash floods. Modern cities need to be prepared for the changing environment in a sustainable way, which can be realised with the help of green infrastructure. The primary role of the green infrastructure is mitigation, such as surface runoff reduction and retainment. The aim of our research is to examine urban district scale data about the role of green infrastructure in urban water management. Hydrological models can provide adequate data about the surface runoff, infiltration and the mitigating effect of vegetation (interception and evaporation). We compared two significantly different urban districts (downtown and housing estate area), based on land cover and vegetation data. The analysis of the districts of Szeged (Hungary) suggests that the vegetation can significantly contribute to the reduction of surface runoff. Differences between these urban districts can be quantified, thus, these data can serve as a basis for urban water management planning processes.
\end{abstract}

Keywords: green infrastructure, i-Tree Hydro, nature-based solutions, sustainability, water management, urban hydrology

Received April 2021, accepted November 2021

\section{Introduction}

The hydrological parameters of urban areas are undergoing significant artificial changes, which can be traced back to a variety of reasons (Fletcher, T.D. et al. 2013). The pavement materials and sewer systems change the properties of surface and groundwater. As a result of preferred impervious surfaces, the amount of surface runoff increases, in contrast to the storage and the residence time (Rodriguez, F. et al. 2008; MejíA, A.I. and Moglen, G.E. 2010; KJeldsen, T.R. et al. 2013; SAmoueI, S. and Özger, M. 2020). Examining these processes is timely, as urban spatial and population growth is a fundamental trend in the $21^{\text {st }}$ century (UN 2013; WiLby, R.L. 2019).
The flood hydrograph of the predominantly artificially paved areas changes drastically, for which reason is short travel time and intense flood waves can be expected (SHUSTER, W.D. et al. 2005; LU, W. and QIN, X. 2020). Weather extremes that are intensifying as a result of climate change, such as heavy rainfall events, urban flash floods and droughts, are also having an impact on urban areas (van de Ven, F.H.M. 1990; Schmitt, T.G. et al. 2004; JHA. A.K. et al. 2012).

Each part of the city may have significantly different land cover, so for example, the proportion of vegetation largely determines the efficiency of mitigation (Figure 1). The study of the various hydrological processes ongoing within districts characterised by different

\footnotetext{
${ }^{1}$ Department of Climatology and Landscape Ecology, University of Szeged. Egyetem u. 2. H-6722 Szeged, Hungary. E-mails: cseteakos@geo.u-szeged.hu, agulyas@geo.u-szeged.hu
} 

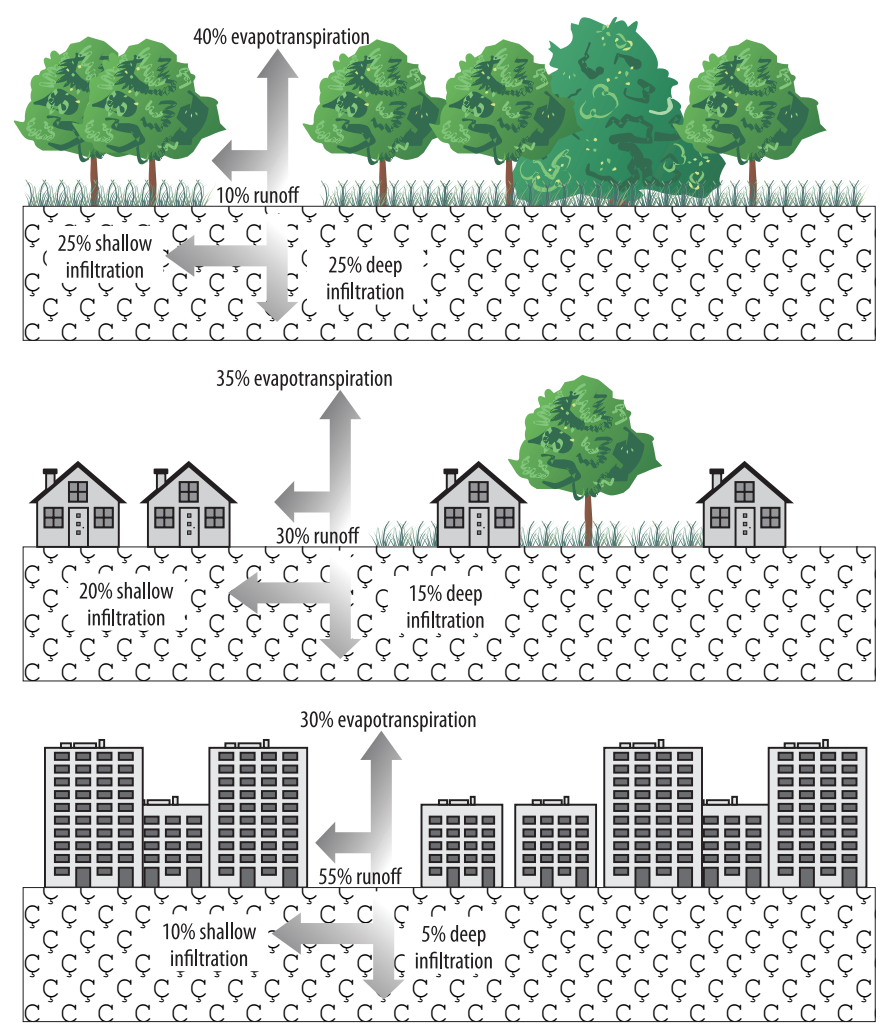

Fig. 1. Hydrological processes of different urban land cover (based on FISRWG 1998)

on hydrological processes through interception (XIAO, Q. and McPherson, E.G. 2002; Holder, C.D. and Gibbes, C. 2016; Berland, A. et al. 2017; HuANG, J.Y. et al. 2017; Kuehler, E. et al. 2017). The damping effects of urban trees and other green space elements are getting increasingly recognised and, thus, used to reduce the negative impact of urbanisation on the water cycle (BrEARs, R.C. 2018; Chatzimentor, A. et al. 2020). With these natural tools used in the place of grey infrastructure, urban water management can be made more sustainable and cost-effective, as well as a more liveable environment for the citizens. By combining green infrastructure with traditional elements, complex solutions can be created which have the potential to reduce extreme and unwanted impacts (Liv, C.M. et al. 2015;

land cover structures is especially important. In order to install a drainage system with a high enough capacity to meet the demands of its city, knowledge about the expected volume of district level runoff, evaporation and infiltration are paramount (THORNDAHL, S. et al. 2006; LI, C. et al. 2018). In addition to the artificial geometric elements (buildings, surface infrastructure), the different land cover and surface morphology of the districts are shaped by the urban vegetation (RomNÉE, A. et al. 2015; SAlvadore, E. et al. 2015).

Urban green spaces have multiple positive social and ecological effects on a city and its residents (Kolcsár, R.A. et al. 2021). Among the elements of green infrastructure - due to their size - the trees should be highlighted, which can also have a significant impact
Berland, A. et al. 2017; Prudencio, L. and NuLL, S.E. 2018).

Knowledge of district level processes is also essential because most sustainable urban water management systems also focus on tackling problems at the local level. In addition to sustainable systems such as Low Impact Development (LID), Sustainable Urban Drainage Systems (SUDS), Water Sensitive Urban Design (WSUD), newer initiatives (Sponge cities) are building on the need to address water-related problems on local levels (Dietz, M.E. 2007; Fletcher, T.D. et al. 2015; Liv, C.M. et al. 2015; Palla, A. and GNeCCO, I. 2015; MaK, C. et al. 2017). As a part of the sustainable urban water management systems, in addition to the importance of green infrastructure, it is necessary to em- 
phasise the role of blue infrastructure. Blue infrastructural elements can be basically defined as the natural or semi-natural elements of the water network, which can also be found in urban environments (HAAsE, D. 2015; BREARS, R.C. 2018). These natural infrastructural elements can be applied at the system level - the so-called nature-based solution (NBS) - which is outstandingly popular in today's urban planning (FRANTZESKAKI, N. 2019).

The main goal in our research was to use hydrological modelling to examine districts with different land cover and to compare the hydrological processes taking place in their area, with a special focus on the role of vegetation in reducing runoff. In urban areas, due to the complexity and diversity of the environment, it is important to use a model that prioritises vegetation not just as a land cover class (Jayasooriya, V.M. and NG, A.W.M. 2014; Pappalardo, V. et al. 2017; Coville, R. et al. 2020). In addition, it is important that the extent of surface runoff is handled accurately and exactly by the model. Based on these considerations and our previous research, the USDA Forest Service i-Tree Hydro (version 5) model was chosen (NowAK, D.J. et al. 2018).

\section{Study sites and data}

The study sites are located in Szeged, which is the central city of the Southern Great Plain Region of Hungary (168,000 inhabitants) (KSH 2013). The area is characterised by high sunshine duration and relatively low rainfall (the region is one of the most arid areas in the country). Consequently, the area is heavily exposed to drought during the summer, which can be interrupted by intense rainfall (BARTHOLY, J. et al. 2014; SÁBitz, J. et al. 2014; Mezósi, G. et al. 2016). Because of climate change, a more extreme distribution of summer precipitation is predicted (BALÁzs, B. et al. 2009). The annual precipitation of 2015 - which was the base year of the modelling - was $450 \mathrm{~mm}$, (slightly below the annual average) in Szeged.
The area of Szeged was significantly transformed by the "big flood" in 1897, as a result of which a new radio-centric plan was formed. This design has significantly influenced the future urban planning processes (UNGER, J. and GÁL, T. 2017).

One of our study sites is located in the strongly built-up downtown (further on in this document: Site1), while the other is located in the outer, housing estate part of the city (further on in this document: Site2), which is a typical cityscape in larger Hungarian cities (Figure 2, Photo 1). Study sites with distinct building geometry and green space coverage provide a good basis for detecting and quantifying the various hydrological properties that are present within the city. The selection of the study sites was based on the system of Local Climate Zones (LCZ) in Szeged (UNGER, J. et al. 2014). In order to delineate these areas, a number of aspects are taken into account, such as land cover and surface geometry, which also indicate the expected hydrological conditions of the area. Being similar in size was one of the primary factors of the study site selection. Due to the alignment to the road network and buildings, however, there are still differences between these areas regarding their size. In order to avoid bias due to spatial differences, the data for the larger study site (Site2) were projected onto the size of the smaller sample area (Site1) (Figure 2).

Site 1 is located in the downtown region, hence it is dominantly characterised by impervious area at the expense of green areas (LCZ 3) (UNGER, J. et al. 2014). A significant part of these green areas are alleys, but two larger urban parks are also present on the study site. The total area of the study site is 60.7 ha. The rate of impervious area is 61 percent $(81 \%$, if the impervious surfaces under the tree canopy are included), and the tree canopy coverage is 31 percent of the area, while the herbaceous cover is around 7 percent (Figure 3 and 5). The annual precipitation is $450 \mathrm{~mm}$, which means $273,268 \mathrm{~m}^{3}$ of rainfall fell on Site1.

Site2 is located in the north-eastern part of Szeged (LCZ 5), which can be characterised by midrise buildings and larger open spaces 

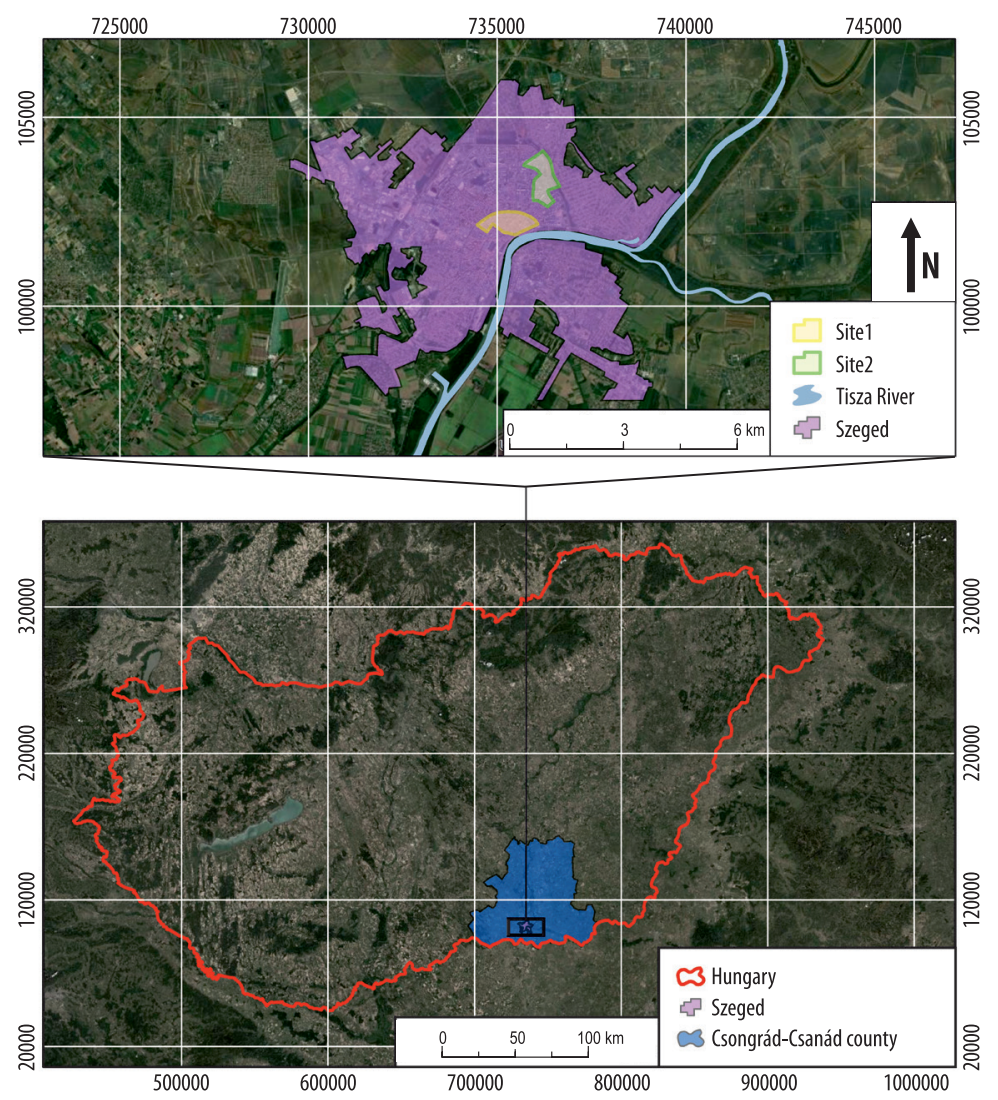

Fig. 2. The spatial location of Szeged and the orientation of the study sites within the city

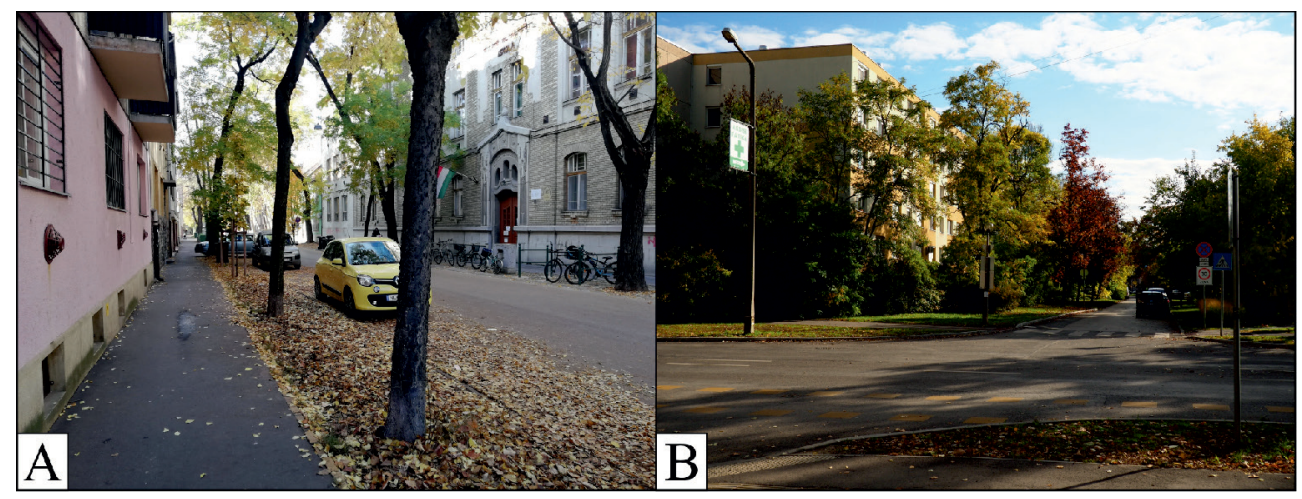

Photo 1. The spectacle in the study sites: Site1 (A), and Site2 (B). (Photo taken by the authors) 

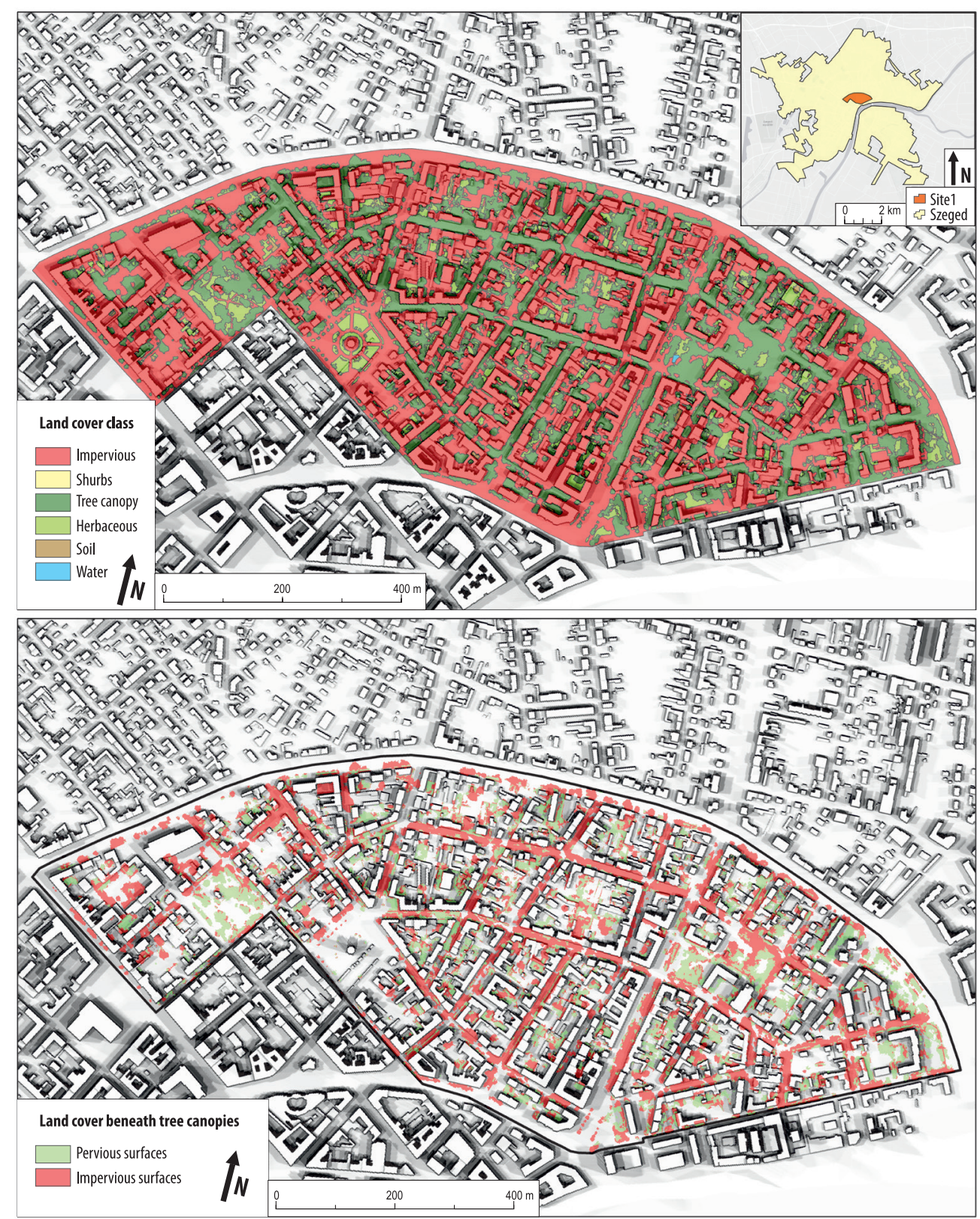

Fig. 3. Land cover proportion in Site1

(Unger, J. et al. 2014). The total area of Site2 is 65.3 ha. The open spaces are covered with herbaceous and woody vegetation. The proportion of the impervious area is 41 percent
(63\%, if the impervious surfaces under the tree canopy are included). The tree canopy covers 43 percent of the area, while the herbaceous coverage is considerably more $(14 \%)$, than in 
the case of Site1 (Figure 4 and 5). In 2015 approximately $294,013 \mathrm{~m}^{3}$ of rainfall fell on Site2.

These data show notable differences between the study sites in land cover, which also predicts differences in the hydrological processes (Figure 5). Site2 is a typical housing estate area. Since housing estate areas are present in virtually every city in the post-socialist countries, this study may potentially provide useful information not only for Szeged but also for most cities in Central and Eastern Europe.
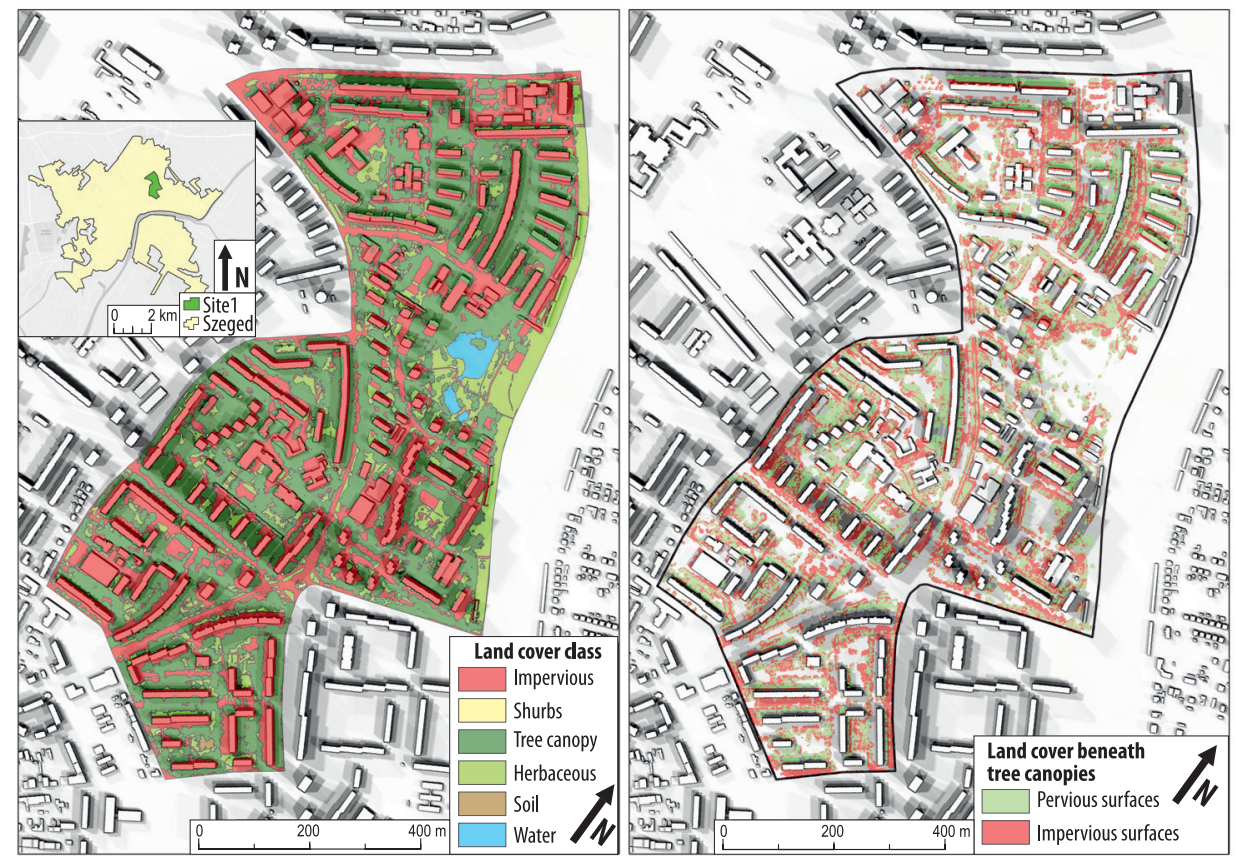

Fig. 4. Land cover proportion in Site2

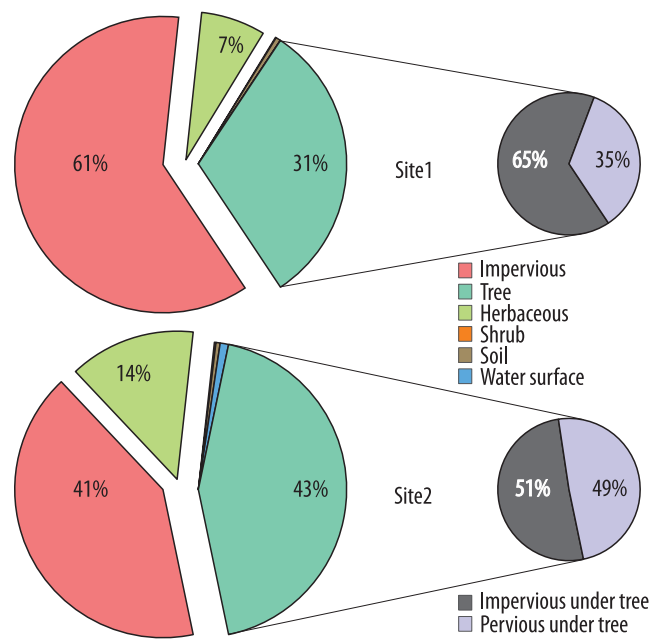

Fig. 5. The land cover proportion of the study sites and the cover beneath under tree canopies 


\section{Methods}

For the modelling of the hydrological processes, the USDA Forest Service i-Tree Hydro model (in the following: Hydro) was used. Unlike any other similar models, Hydro has the advantage to focus on vegetation in the urban environment. It can be used for a more accurate investigation of the relationships between precipitation and vegetation. The results can provide data on surface runoff (and its distribution on different surfaces), vegetation processes (interception, evaporation) and infiltration (WANG, J. et al. 2008; Hirabayashi, S. and Endreny, T.A. 2016). Since i-Tree Hydro was optimised to study areas within the United States, its adaptation to European cities had serious limitations.

The model calculates the outputs based on three main groups of input data: meteorological, land cover, and soil data (WANG, J. et al. 2008; Hirabayashi, S. and ENDrENY, T.A. 2016). The basic data of the model are from 2015. The main parameters of meteorological data include liquid and solid precipitation, wind speed, air temperature, dew point and net radiation. The inputs come from comprehensive databases and have undergone multiple processing (i-Tree 2016). The meteorological data is provided by the Department of Climatology and Landscape Ecology of Szeged and the Szeged synoptic station.

One of the most important databases in the model contains the land cover categories of the study sites. To this end, it is necessary to classify land cover into six classes: impervious areas, trees, shrub vegetation, herbaceous vegetation, soil and water surface. Furthermore, it is necessary to define the land cover beneath the tree canopy according to impervious and pervious categories (iTree 2016). In order to define the land cover categories, eCognition 9.1. software was used through performing segment-based multiresolution classification. The designation of the categories was divided into two stages. In the first stage, the traditional land cover categories were specified. To create the basic categories, a 4-band Ultra Cam X orthophoto
(2015) with a geometric resolution of $0.4 \mathrm{~m}$ was used. In addition to the orthophoto, a digital surface model (DSM) from 2015, a normalised digital surface model (nDSM) and a digital elevation model (DEM) were also utilised as additional data (Lechner Knowledge Center, 2015). An NDVI vegetation index map derived from the orthophoto was used to refine the vegetation categories.

In the first step, multi-resolution segmentation was used on the orthophoto and the other additional data (DSM, NDVI etc.) to create the basis of the classification. In the next step, with the help of the NDVI, the data was separated into two main classes: vegetation and non-vegetation classes. After this step, the water, soil, and impervious categories were delineated with the use of different limit values and manual classification. We also used a building database of Szeged to filter out buildings (Department of Climatology and Landscape Ecology of the University of Szeged). For better differentiation within the vegetation category, we used DSM and $\mathrm{nDSM}$ data. With the help of these, the three different vegetation types (trees, shrubs, herbaceous vegetation) were delineated based on their height. In the next step, the categories beneath the tree canopy were classified. A 3-band orthophoto from 2011 with a geometric resolution of $0.1 \mathrm{~m}$ (Department of Geoinformatics, Physical and Environmental Geography of the University of Szeged) was used to categorise the surface under the tree canopy. In this step, only the surfaces under the tree canopies were used. For this delineation, we relied on manual classification in eCognition. The result of these two classification processes was a high-precision land cover category map, completed by a highprecision sub-canopy database (Figure 6).

For the third input category, it is necessary to provide pedological data, which were derived from the data of a field survey (FEJEs, I. 2014). Regarding the physical soil type, there are only minimal differences between the two study sites, meaning that based on the data, the soil of both sites can be defined as sandy clay loam. Differences occurred in 


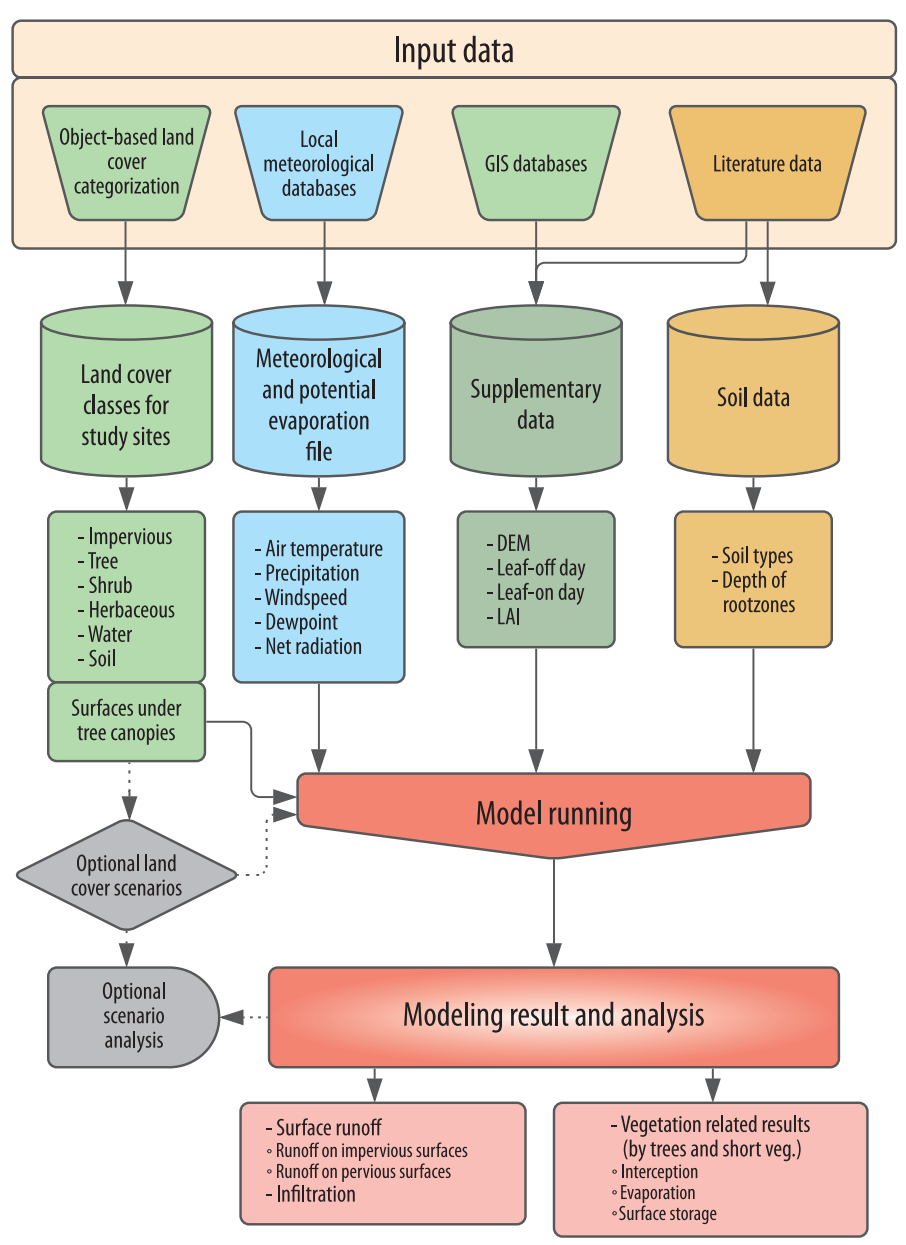

Fig. 6. The structure of the assessment and the modelling results

the runoff of impervious as well as pervious surfaces supplemented by the baseflow (WANG, J. et al. 2008). Infiltration can also be concluded from this data. Taking into account the land cover data and the soil data, the model also calculates the volume of infiltrated precipitation (using the Green-Ampt infiltration equations). The role of vegetation can be shown by interception, evaporation, and surface storage. These processes can be divided into trees and short vegetation (which includes herbaceous and shrub vegetation) (Shuttleworth, W.J. 1992; WANG, J. et al. 2008; Hirabayashi, S. and Endreny, T.A. 2016) (see Figure 6).

\section{Results}

\section{Runoff-related results}

The total runoff was estimated to be $140,595 \mathrm{~m}^{3}$ in Site1 (51\% of the total precipitation) and $120,643 \mathrm{~m}^{3}$ (44\% of

the depth of the root zone (Site1 $50 \mathrm{~cm}$, Site2 $100 \mathrm{~cm}$ ). Besides that, there are some other necessary soil inputs that need to be added to the model (surface hydraulic conductivity, initial soil saturation condition), and in the advanced options, more attributes can be added (e.g. transmissivity at saturation, pervious/impervious depression storage, transmissivity at saturation, soil macropore percentage etc.). The soil data affects the volume of runoff and infiltration, so specifying them accurately is paramount.

The most important output data is the total runoff, which consists of three components: the total precipitation) in Site2. These results imply a relationship between total runoff and the land cover structure. The total runoff of the study sites per month shows a similar rate (mostly lower in Site2, with the exception of October and November) (Figure 7).

By looking at the subcategories of the runoff of the study sites, significant differences can be detected. The runoff of Site1 is determined by runoff on the impervious surfaces each month. The runoff of the impervious surfaces during the year shows a broadly uniform picture, with the exception of the months with low precipitation. The propor- 


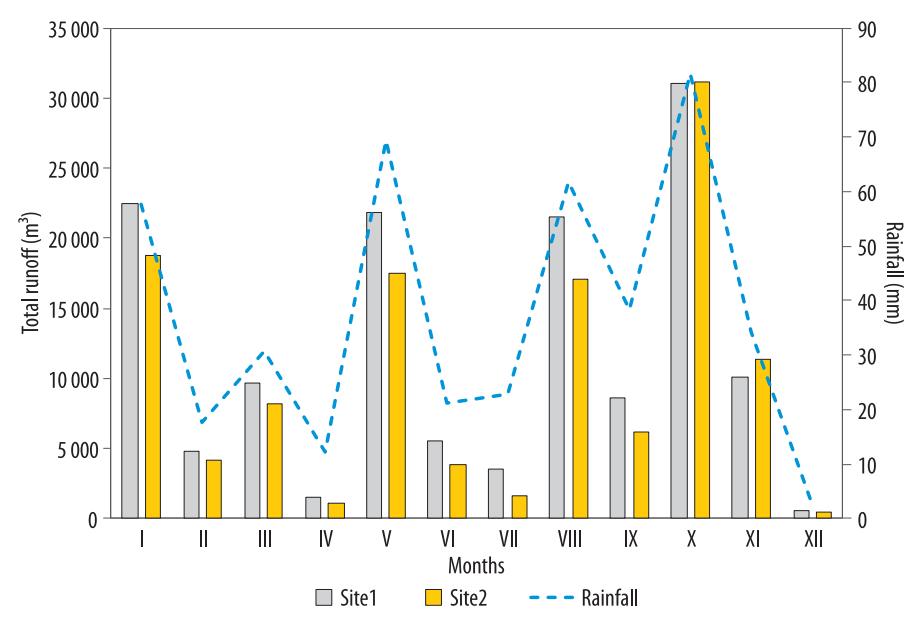

Fig. 7. Total runoff per month in study sites runoff vast majority of it is flowing on an impervious surface. Infiltration is only 29 percent of the precipitation. A large proportion of the rainfall is being drained away in the downtown area, and only a small proportion of it infiltrates into the soil. In the housing estate area (Site2), the volume of runoff is lower compared to Site1, and a larger part of it flows on pervious surface (Table 1). The infiltration rate is 35 percent, meaning

tion of the baseflow increased in December and April compared to the other components of the total runoff (Figure 8).

In the case of Site2, due to the different land cover structures (higher proportion of pervious surfaces), different runoff ratios are observable. In this case as well - similarly to Site 1 - months with low rainfall are the exceptions. During these months, the ratio of the baseflow relative to the other components of the total runoff is higher than in the case of the other months. These months are respectively April, July and December (Figure 9).

The differences between the two areas are also reflected in the total volume of runoff throughout the year. Site1 has a higher runoff rate due to lower vegetation cover, lower pervious surface ratio and, thus, less efficient infiltration than Site2. In Site2, there is 7 percent less runoff during the year, which means approximately $20,000 \mathrm{~m}^{3}$ difference.

In the runoff of pervious and impervious surfaces, an opposite ratio can be observed between the two study sites, which is also due to the differences in land cover. Infiltration is also higher due to the higher proportion of pervious surfaces Site2. Due to its high building coverage, sparse vegetation and, thus, infiltration rate, Site1 in the downtown has significantly more surface

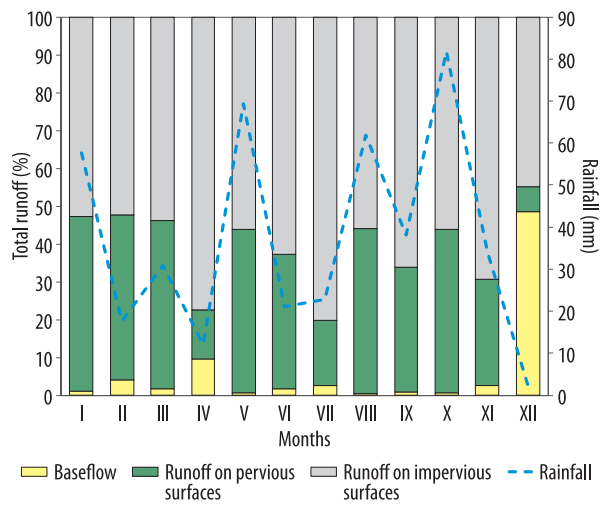

Fig. 8. Runoff subcategories at Site1 per month

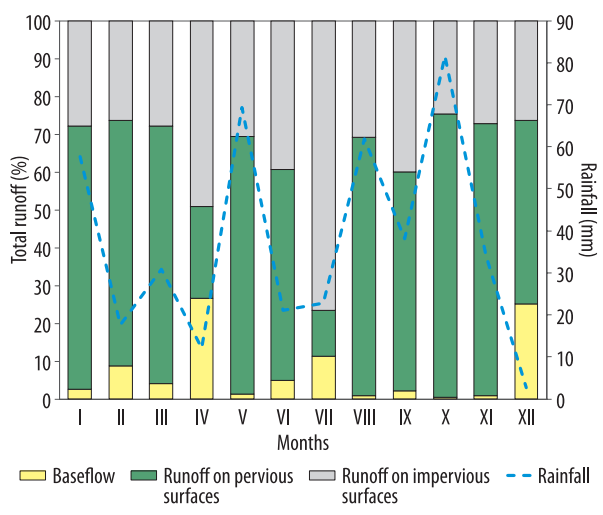

Fig. 9. Runoff subcategories at Site2 per month 
Table 1. The runoff-related results by study sites

\begin{tabular}{|c|c|c|c|}
\hline Processes, $\mathrm{m}^{3}$ & Site1 & Site2 & Site 2 original \\
\hline Total runoff & 140,595 & 120,643 & 129,802 \\
\hline Baseflow & 1,936 & 2,622 & 2,821 \\
\hline Runoff on pervious surfaces & 57,304 & 82,435 & 88,693 \\
\hline Runoff on impervious surfaces & 81,355 & 35,586 & 38,287 \\
\hline Infiltration & 78,416 & 94,703 & 101,892 \\
\hline Precipitation & 273,268 & 273,268 & 294,013 \\
\hline
\end{tabular}

a larger volume of precipitation infiltrates in this case (Figure 10). According to the preliminary assumptions, the hydrological conditions in Site 2 are more favourable from the point of view of water management. In Site1, water management development is also hampered by the fact that the densely built-up urban structure is hard to modify, so there is little chance that large-scale changes can be made in the area.

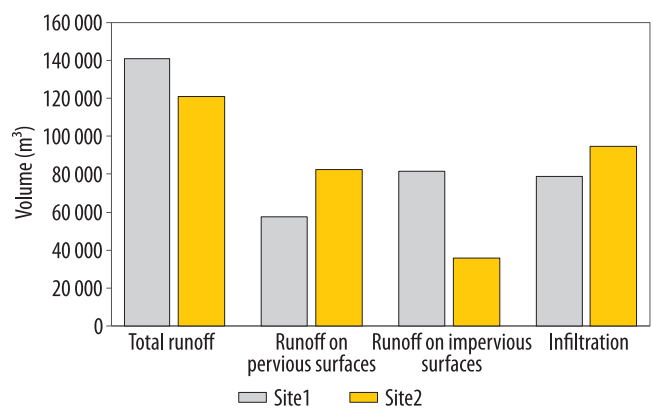

Fig. 10. Summarised runoff-related processes by study sites

\section{Vegetation-related results}

The role of vegetation in hydrological processes was investigated through two vegetation categories. One is the short vegetation (which includes herbaceous and shrub vegetation), and the other is the trees. Due to their size, as well as their structural and spatial proportions in the study sites, trees play a key role in modifying hydrological processes. The proportion of trees is significantly higher in Site2 than in Site1, which predicts higher interception and evaporation values.

Due to the higher tree canopy coverage, a larger volume of precipitation fell on the tree canopy in the case of Site2, with almost $35,000 \mathrm{~m}^{3}$. The volume of interception for Site1 is $10,502 \mathrm{~m}^{3}$ (3.8\% of the total precipitation) and $14,759 \mathrm{~m}^{3}(5.4 \%$ of the total precipitation) for Site2. It is observable that the larger extent of the tree canopy cover makes a higher amount of interception possible. Consequently, housing estates located in more open areas have a fundamentally higher green infrastructural value than downtown areas (Figure 11). Evaporation shows similar proportions. According to the calculation method of the model, captured rainwater completely evaporates from the surface of the vegetation.

Due to the ratio of short vegetation's structural properties (less surface area to retain precipitation), less water is absorbed, resulting in milder evaporation. In the case of Site2, the interception of short vegetation was $2,020 \mathrm{~m}^{3}(0.7 \%$ of the precipitation of

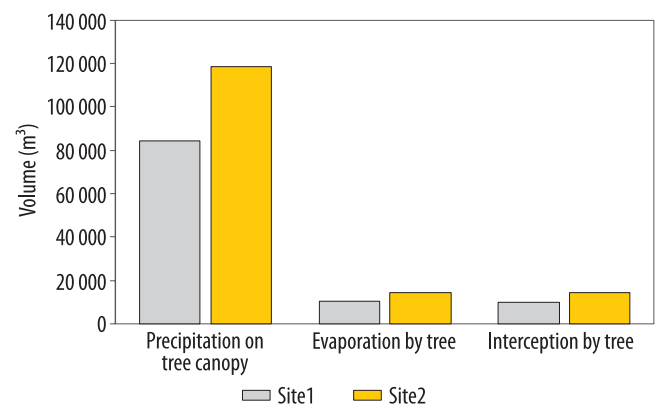

Fig. 11. Tree-related processes by study sites 
the total area), while in the case of Site1 it was only $1,030 \mathrm{~m}^{3}(0.4 \%$ of the precipitation of the total area). Based on these, it can be seen that the interception of the study sites is fundamentally influenced by the trees, while the short vegetation - due to their smaller surface area - has a less important role in the process. Due to the difference between the study sites, vegetation's contribution to rainwater retention is much higher in the housing estate area than in the denser, downtown study site (Figure 12).

The monthly volume of interception is primary based on precipitation, the length of vegetation period (between 200 and 215 days - Rötzer, T. and Chmielewski, F.M. 2001), however, also influences its change. Comparing months with high precipitation in different seasons (e.g. January, May, August and October), clearly visible differences can be detected. In January and August, while the amount of precipitation was almost the same (58-62 mm), interception differed by almost twice as much (Figure 13 and 14). In August, due to the active vegetation period, the vegetation was able to retain precipitation at a much higher rate than in January with almost the same volume of precipitation. Similar trends are observed between October and May with the former having higher precipitation associated with a lower interception rate compared to the latter.

Interception efficiency (the proportion of withheld rainwater relative to the total fallen precipitation) is higher the more arid a month

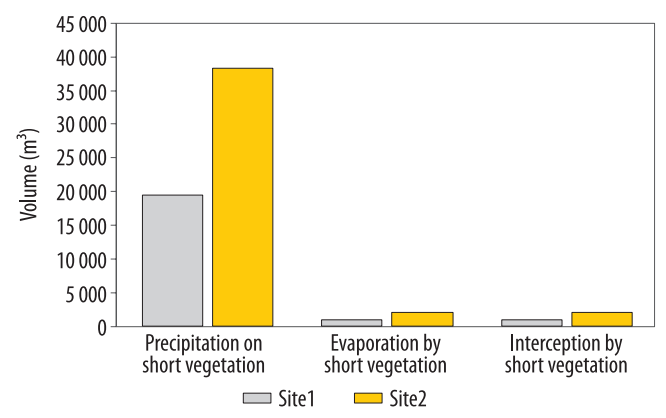

Fig. 12. Short vegetation-related processes by study sites

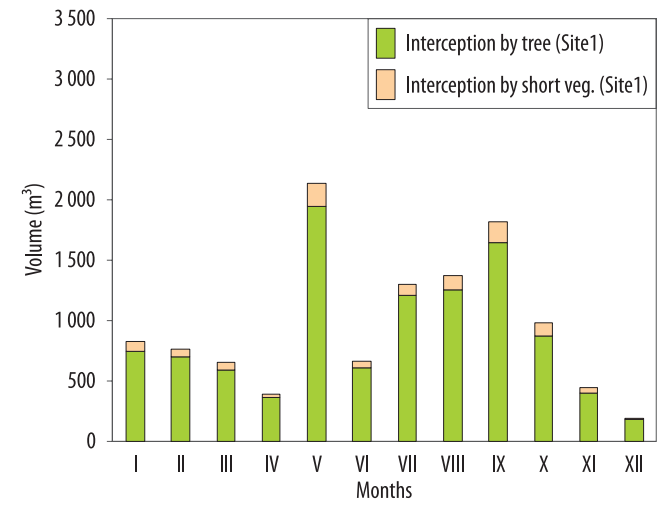

Fig. 13. Interception at Site1

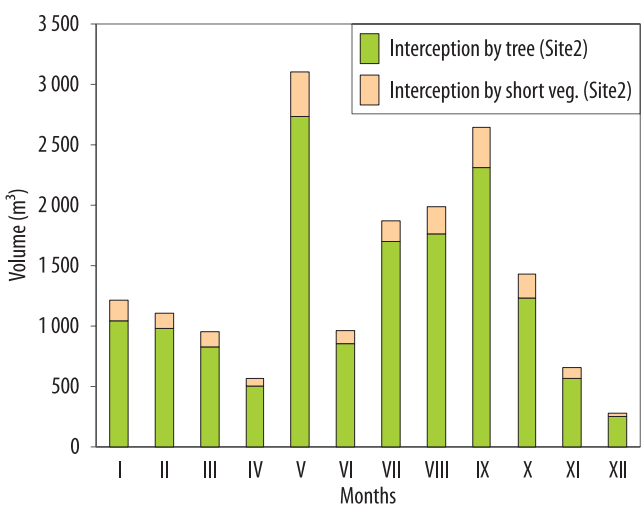

Fig. 14. Interception at Site2

is (Figure 15). This phenomenon is caused by the fact that in the case of lower precipitation volume and intensity, the storage capacity of the tree canopy does not reach its maximum, while in the case of a large volume of precipitation, the canopy becomes saturated. The leaf storage maximum values are the highest in the vegetation period (Figure 16). When the tree canopy reaches the maximum storage capacity, excess precipitation will not be stored, thus, worsening the precipitationinterception ratio (see Figure 15 and 16).

By looking at the interception efficiency, it can be seen that these values are mostly high- 


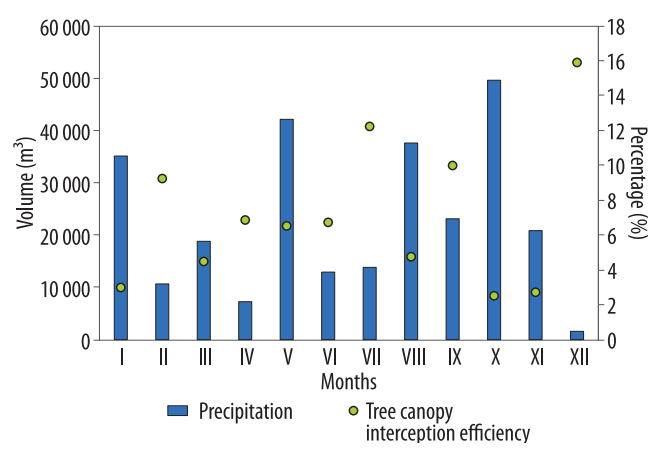

Fig. 15. Tree canopy interception efficiency at Site2

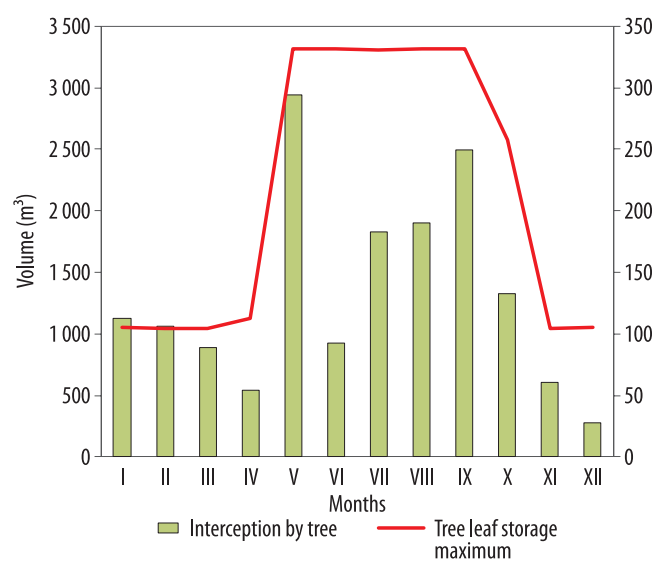

Fig. 16. Tree canopy interception and leaf storage maximum at Site2

er during the vegetation period (additionally in December as well, when the precipitation is minimal), resulting in the volume of intercepted water by the vegetation in a larger proportion during the vegetation period (see Figure 15).

\section{Discussion}

Results showed notable differences in the hydrological processes between the study sites meeting the preliminary expectations of the study. Runoff and infiltration are greatly influenced by the differences in the ratio of the various land cover types, as noticed in other researches (Shuster, W.D. et al. 2005; Li, C. et al. 2018; ZHANG, N. et al. 2018).

In the city centre (Site1) - characterised by a higher ratio of impervious areas - the surface runoff is higher than in the open, housing estate part of the city. This is caused by the higher proportion of impervious surfaces, such as lower infiltration rate and lower vegetation cover, similarly to the results of LI, C. et al. 2018. The difference is 7 percent, which means nearly $20,000 \mathrm{~m}^{3}$ of rainwater per year. The infiltration is higher in Site2 due to the higher ratio of pervious surfaces (BRUN, S.E. and BAND, L.E. 2000; JACOBSON, C.R. 2011). In Site1 the infiltration is only 29 percent of the precipitation in contrast with Site 2 where the infiltration is 35 percent of the precipitation.

In the study site with high vegetation coverage (Site2), trees contributed to the lower value of surface runoff through interception. Tree canopy induced total runoff reduction has an important role in support of urban water management systems by making the surface flooding and sewerage network overloading events less frequent in this area. Among the vegetation elements, trees contribute the most to the reduction of runoff. This is caused by their size and structural parameters (BERLAND, A. et al. 2017), as well as by their ratio within the study site. The interception efficiency of vegetation is the highest during the vegetation period, but the influence of the time distribution and amount of precipitation are not negligible either. In Site 2 the interception of short vegetation is $2,020 \mathrm{~m}^{3}$ while the interception of the trees is $14,759 \mathrm{~m}^{3}$, in opposition to Site1, where the interception of short vegetation is $1,030 \mathrm{~m}^{3}$ while the interception of the trees is $10,502 \mathrm{~m}^{3}$. Due to the difference between these sites, vegetation's contribution to precipitation retention is higher in the housing estate area than in the downtown study site (LI, C. et al. 2018).

There are not many available studies with i-Tree Hydro in urban areas, furthermore, these studies investigated significantly larger study areas than ours. A research in Bogotá 
(Colombia) investigated a study area of $33.26 \mathrm{~km}^{2}$, and in another assessment in Luohe (China) a $75.2 \mathrm{~km}^{2}$ study area was chosen. In contrast with these the study areas in our assessment are $0.65 \mathrm{~km}^{2}$ and $0.6 \mathrm{~km}^{2}$ (BAutista, D. and Peña-Guzmán, C. 2019; Song, P. et al. 2020). In the assessment of SonG, P. et al. (2020), scenario analysis was used. They ascertained the increased proportion of green spaces could reduce the surface runoff. This is in line with our findings that the study site with a larger green cover has better water management properties. They highlighted that the vegetation, as part of the green infrastructure, has positive effects on runoff reduction, but on its own, the vegetation/green spaces do not have enough capacity to avoid urban flooding. Based on our assessment, we can also conclude that vegetation decreases surface runoff; however, with the increase of permeable surfaces, the efficiency of runoff mitigation can be further enhanced. SoNG, P. et al. (2020) divided the interception efficiency investigation of trees into two groups. Leaf-on period during the year means the vegetation period, while the leaf-off period means the phase when the vegetation is in a bare state. SonG, P. et al. (2020) stated that the interception efficiency is higher in the vegetation period, which coincides with our results. BAUTista, D. and Peña-Guzmán, C. (2019) also highlighted the necessity for permeable surfaces. In their assessment, the increment of permeable surfaces under tree canopies had a significant improvement in surface runoff reduction. This fact is of key importance because in the case of the study sites of Szeged, the impervious surfaces beneath tree canopies have a high proportion, which needed further investigation.

The study sites of Szeged have different characteristics, and therefore need different management and green infrastructure developments. The SC1 is characterised by impervious areas and dense building coverage. There are many old buildings and a narrow road network between them. This structure fundamentally determines and limits development opportunities. The buildings cannot be demolished, nor can geometric structures be changed. Therefore, developments are limited to a smaller scale. Smaller-scale green infrastructure and sustainable water management tools have various forms. One of the obvious solutions is the raingardens which can be applied in narrow spaces and can reduce the local surface runoff. They also have a temporary storage capacity. The other feasible improvement is to increase the proportion of the permeable / pervious surfaces. With the permeable concrete or asphalt, parking areas can be made more sustainable, especially if they are supplemented by underground stormwater tanks. In the SC2 the urban planners have more opportunities due to larger open spaces. In this study site, the buildings are at a greater distance from each other, and the proportion of impervious surfaces is lower than in the SC1. Within the study site, a storm basin lake already exists. In addition to the solutions listed at the SC1 - which can also be implemented here - swales and infiltration trenches can increase the infiltration and reduce the surface runoff within SC2.

The i-Tree Hydro model is an appropriate tool to evaluate the role of vegetation in the urban water cycle and water management options. There are only a few tools that build on vegetation in such detail. Nevertheless, its spread is hampered by a few factors. First of all, the model was developed in the US and is therefore optimised for US databases, international use is relatively complicated (and therefore rare). Obtaining and compiling the necessary data is encounter difficulties, especially the meteorological and discharge data within cities. The data supply in Hungary limits the possibilities of model calibration and validation, so we must rely on data from any available international literature (e.g. Bautista, D. and PeñA-Guzmán, C. 2019; Song, P. et al. 2020). These problems are not completely solved in other researches either, where the calibration or validation was possible, the studies were conducted on a larger area, where more data sources were available (Bautista, D. and Peña-Guzmán, C. 2019; Song, P. et al. 2020). More detailed data about the vegetation and its seasonal variability (LAI) can could further strengthen our results. 


\section{Conclusions}

The i-Tree Hydro model utilised in the present research is suitable for modelling the role of vegetation in the urban environment. In this study, two urban districts with different vegetation cover and geometric structures were compared in order to get a comprehensive picture of their differences regarding their hydrological processes. The district-level data provided by the model can be used in urban planning processes. With this information, the runoff of the areas, as well as the vegetation contribution to its reduction were quantified. Studies in this topic might contribute to making nature-based solutions more popular among urban planners and spreading this concept to reach a wider range of professionals and decision-makers.

Data from different districts and their comparison with the processes of the whole urban area can give a comprehensive picture of the processes in the city, but it can also be extended to cities with similar climate and spatial structures. This research may provide a good basis for urban planning in CentralEuropean cities. This assessment has highlighted the advantages and disadvantages of the model and has emphasised some problem that needs to be solved. We have investigated different study sites within Szeged, similar of which can be most likely found be in other Central-European cities. This research has also focused on which types of green infrastructure elements can be feasible in these districts. Hopefully, the modelling can provide a basis for a similar endeavour of urban planners in other cities. While the data and the results might be different in many cities, this method and the main points can nevertheless be used in other cities as well. Future studies in this topic should aim to complete a runoff analysis based on green infrastructure for the entire administrative area of Szeged. Further investigation in connection with the model is planned. Assessment for the whole administrative area of Szeged could give a comprehensive picture about the city-scale usability of the model on a city level and could highlight the differences between the different scales. Another possibility is to create a scenario analysis between different land cover cases. Furthermore, longer time scale investigations may provide more accurate results. Working with hourly resolution output data is a way to analyse the effects of rapid meteorological events, which makes the assessment more current, based on the future climate predictions.

Acknowledgements: Many thanks to the Department of Geoinformatics, Physical and Environmental Geography of the University of Szeged, as well as to the Department of Climatology and Landscape Ecology of the University of Szeged for providing the spatial and meteorological database.

\section{REFERENCES}

Balázs, B., Unger, J., Gál, T., Sümeghy, Z., Geiger, J. and Szegedi, S. 2009. Simulation of the mean urban heat island using 2D surface parameters: empirical modelling, verification and extension. Meteorological Applications 16. (3): 275-287. Doi: 10.1002/met.116

Bartholy, J., Pongrácz, R. and Pieczka, I. 2014. How the climate will change in this century? Hungarian Geographical Bulletin 63. (1): 55-67. Doi:10.15201/ hungeobull.63.1.5

Bautista, D. and PeÑA-Guzmán, C. 2019. Simulating the hydrological impact of green roof use and an increase in green areas in an urban catchment with i-Tree: A case study with the town of Fontibón in Bogotá, Colombia. Resources 8. (2): 68. Doi:10.3390/ resources 8020068

Berland, A., Shiflett, S.A., Shuster, W.D., Garmestani, A.S., Goddard, H.C., Herrmann, D.L. and Hoptonc, M.E. 2017. The role of trees in urban stormwater management. Landscape and Urban Planning 162. 167-177. Doi: 10.1016/j.landurbplan.2017.02.017

Brears, R.C. 2018. Blue and Green Cities: The Role of Blue-green Infrastructure in Managing Urban Water Resources. London, Palgrave Macmillan. Doi: 10.1057\%2F978-1-137-59258-3

BRUN, S.E. and BAND, L.E. 2000. Simulating runoff behaviour in an urbanising watershed. Computers, Environment and Urban Systems 24. (1): 5-22. Doi: 10.1016/S0198-9715(99)00040-X

Chatzimentor, A., Apostolopoulou, E. and Mazaris, A.D. 2020. A review of green infrastructure research in Europe: Challenges and opportunities. Landscape and Urban Planning 198. 103775. Doi: 10.1016/j. landurbplan.2020.103775 
Coville, R., Endreny, T. and NowaK, D.J. 2020. Modelling the impact of urban trees on hydrology. In Forest-Water Interactions. Ecological Studies (Analysis and Synthesis). Eds.: Levia, D.F., CARLYLEMoses, D.E., Iida, S., MichalziK, B., NANKo, K. and Tischer, A., Cham, Switzerland. Springer, 459-488. Doi: 10.1007/978-3-030-26086-6_19

DiETz, M.E. 2007. Low impact development practices: A review of current research and recommendations for future directions. Water, Air, and Soil Pollution 186. 351-363. Doi: 10.1007/s11270-007-9484-z

Fejes, I. 2014. A talaj-és talajvízrendszer komplex környezeti szempontú értékelése városi területen, Szeged példáján (The complex environmental evaluation of the soil-groundwater system in urban areas: The example of Szeged). PhD thesis, Department of Physical Geography and Geoinformatics. Szeged, Hungary. University of Szeged.

FISRWG 1998. Stream Corridor Restoration: Principles, Processes, and Practices. Federal Interagency Stream Restoration Working Group (FISRWG). GPO Item No. 0120-A; SuDocs No. A 57.6/2:EN 3/PT.653. Washington D.C., USDA.

Fletcher, T.D., Andrieu, H. and Hamel P. 2013. Understanding, management and modelling of urban hydrology and its consequences for receiving waters: A state of the art. Advances in Water Resources 51. 261-279. Doi: 10.1016/j.advwatres.2012.09.001

Fletcher, T.D., Shuster, W., Hunt, W.F., Ashley, R., Butler, D., Arthur, S., Trowsdale, S., Barraud, S., Semadeni-Davies, A., Bertrand-Krajewski, J.L., Mikkelsen, P.S., Rivard, G., Uhl, M., Dagenais, D. and VikLANDER, M. 2015. SUDS, LID, BMPs, WSUD and more - The evolution and application of terminology surrounding urban drainage. Urban Water Journal 12. (7): 525-542. Doi: 10.1080/1573062X.2014.916314

FrANTZESKAKI, N. 2019. Seven lessons for planning nature-based solutions in cities. Environmental Science and Policy 93. 101-111. Doi: 10.1016/j.envsci.2018.12.033

HaAse, D. 2015. Reflections about blue ecosystem services in cities. Sustainability of Water Quality and Ecology 5. 77-83. Doi: 10.1016/j.swaqe.2015.02.003

Holder, C.D. and Gibbes, C. 2016. Influence of leaf and canopy characteristics on rainfall interception and urban hydrology. Hydrological Sciences Journal 62. (2): 182-190. Doi: 10.1080/02626667.2016.1217414

Huang, J.Y., Black, T.A., Jassal, R.S. and Les LAVKULICH, L.M. 2017. Modelling rainfall interception by urban trees. Canadian Water Resources Journal 42. (4): 336-348. Doi: 10.1080/07011784.2017.1375865

JAcobson, C.R. 2011. Identification and quantification of the hydrological impacts of imperviousness in urban catchments: A review. Journal of Environmental Management 92. (6): 1438-1448. Doi: 10.1016/j.jenvman.2011.01.018
Jayasooriya, V.M. and NG, A.W.M. 2014. Tools for modelling of stormwater management and economics of green infrastructure practices: A review. Water, Air, and Soil Pollution 225. 2055. Doi: 10.1007/ s11270-014-2055-1

Jha, A.K., Bloch, R. and Lamond, J. 2012. Cities and Flooding: A Guide to Integrated Urban Flood Risk Management for the $21^{\text {st }}$ Century. Washington D.C., World Bank.

KJeldsen, T.R., Miller, J.D. and Packman, J.C. 2013. Modelling design flood hydrographs in catchments with mixed urban and rural land cover. Hydrology Research 44. (6): 1040-1057. Doi: 10.2166/nh.2013.158

Kolcsár, R.A., Csikós, N. and Szilassi, P. 2021. Testing the limitations of buffer zones and Urban atlas population data in urban green space provision analyses through the case study of Szeged, Hungary. Urban Forestry and Urban Greening 57. 126942. Doi: 10.1016/j.ufug.2020.126942

KSH 2013. 2011. évi népszámlálás (Census 2011). Budapest, Központi Statisztikai Hivatal.

Kuehler, E., Hathaway, J. and Tirpak, A. 2017. Quantifying the benefits of urban forest systems as a component of the green infrastructure stormwater treatment network. Ecohydrology 10: e1813. Doi: 10.1002/eco.1813

Lechner Knowledge Center (former Institute of Geodesy, Cartography and Remote Sensing), 2015. Budapest.

Li, C., Liu, M., Hu, Y., Shi, T., Qu, X. and Walter, M.T. 2018. Effects of urbanisation on direct runoff characteristics in urban functional zones. Science of the Total Environment 643. 301-311. Doi: 10.1016/j. scitotenv.2018.06.211

Liu, C.M., Chen, J.W., Hsieh, Y.S., Liou, M.L. and Chen, T.H. 2015. Build sponge eco-cities to adapt hydroclimatic hazards. In Handbook of Climate Change Adaptation. Ed.: Leal Filho, W., BerlinHeidelberg, Springer, 1997-2009. Doi: 10.1007/9783-642-38670-1_69

LU, W. and QIN, X. 2020. Integrated framework for assessing climate change impact on extreme rainfall and the urban drainage system. Hydrology Research 51. (1): 77-89. Doi: 10.2166/nh.2019.233

Mak, C., Scholz, M. and James, P. 2017. Sustainable drainage system site assessment method using urban ecosystem services. Urban Ecosystem 20. 293-307. Doi: 10.1007/s11252-016-0593-6

Mejía, A.I. and Moglen, G.E. 2010. Impact of the spatial distribution of imperviousness on the hydrologic response of an urbanising basin. Hydrological Processes 24. 3359-3373. Doi: 10.1002/hyp.7755

Mezôsi, G., Blanka, V., Ladányi, Zs., Bata, T., UrdeA, T., Frank, A. and Meyer, B.C. 2016. Expected midand long-term changes in drought hazard for the south-eastern Carpathian Basin. Carpathian Journal of Earth and Environmental Sciences 11. (2): 355-366. 
NowaK, D.J., Maco, S. and Binkley, M. 2018. i-Tree: Global tools to assess tree benefits and risks to improve forest management. Arbor Consultant 51. (4): 10-13.

Palla, A. and Gnecco, I. 2015. Hydrologic modelling of Low Impact Development systems at the urban catchment scale. Journal of Hydrology 528. 361-368. Doi: 10.1016/j.jhydrol.2015.06.050

Pappalardo, V., La Rosa, D., Campisano, A. and La GrecA, P. 2017. The potential of green infrastructure application in urban runoff control for land use planning: A preliminary evaluation from a southern Italy case study. Ecosystem Services 26. Part B. 345-354. Doi: 10.1016/j.ecoser.2017.04.015

Prudencio, L. and Null, S.E. 2018. Stormwater management and ecosystem services: a review. Environmental Research Letters 13. 033002. Doi: 10.1088/1748-9326/aaa81a

Rodriguez, F., Andrieu, H. and Morena, F. 2008. A distributed hydrological model for urbanised areas - Model development and application to case studies. Journal of Hydrology 351. (3-4): 268-287. Doi: 10.1016/j.jhydrol.2007.12.007

Romnée, A., Evrard, A. and Trachte, S. 2015. Methodology for a stormwater sensitive urban watershed design. Journal of Hydrology 530. 87-102. Doi: 10.1016/j.jhydrol.2015.09.054

Rötzer, T. and Chmielewski, F.M. 2001. Phenological maps of Europe. Climate Research 18. (3): 249-257. Doi: 10.3354/cr018249

Sábitz, J., Pongrácz, R. and Bartholy, J. 2014. Estimated changes of drought tendency in the Carpathian Basin. Hungarian Geographical Bulletin 63. (4): 365-378. Doi: 10.15201/hungeobull.63.4.1

Salvadore, E., Bronders, J. and BatelaAn, O. 2015. Hydrological modelling of urbanised catchments: A review and future directions. Journal of Hydrology 529. Part 1. 62-81. Doi: 10.1016/j.jhydrol.2015.06.028

SAmoueI, S. and Özger, M. 2020. Evaluating the performance of low impact development practices in urban runoff mitigation through distributed and combined implementation. Journal of Hydroinformatics 22. (6): 1506-1520. Doi: 10.2166/ hydro.2020.054

Schmitt, T.G., Thomas, M. and Eтtrich, N. 2004. Analysis and modeling of flooding in urban drainage systems. Journal of Hydrology 299. (3-4): 300-311. Doi: 10.1016/j.jhydrol.2004.08.012

Shuster, W.D., Bonta, J., Thurston, H., WARnemuende, E. and Smith, D.R. 2005. Impacts of impervious surface on watershed hydrology: A review. Urban Water Journal 2. (4): 263-275. Doi: 10.1080/15730620500386529

SHutTLEWORTH, W.J. 1992. Evaporation. In Handbook of hydrology. Ed.: Maidment, D.R., New York, NY, McGraw Hill, 4.1-4.53.

Song, P., Guo, J., Xu, E., Mayer, A.L., Liu, C., Huang, J., Tian, G. and KIM, G. 2020. Hydrological effects of urban green space on stormwater runoff reduction in Luohe, China. Sustainability 12. (16): 6599. Doi:10.3390/su12166599

Thorndahl, S., Johansen, C. and SchaArup-Jensen, K. 2006. Assessment of runoff contributing catchment areas in rainfall runoff modelling. Water Science and Technology 54. (6-7): 49-56. Doi: 10.2166/ wst.2006.621

UN 2013. World Population Prospects: The 2012 Revision, Highlights and Advance Tables, Report ESA/P/ WP.228, New York, United Nations, Department of Economic and Social Affairs, Population Division.

Unger, J., Lelovics, E. and GÁl, T. 2014. Local climate zone mapping using GIS methods in Szeged. Hungarian Geographical Bulletin 63. (1): 29-41. Doi: 10.15201/hungeobull.63.1.3

UNGER, J. and GÁL, T. 2017. Városklíma-Szeged városklimatológiai vonatkozásai (Urban climate - Urban climatological aspects of Szeged). Szeged, GeoLitera.

VAN DE VEN, F.H.M. 1990. Water balances of urban areas. Hydrological processes and water management in urban areas. International Association of Hydrological Sciences Publication 198. 21-32.

WANG, J., Endreny, T.A. and Nowak, D.J. 2008. Mechanistic simulation of tree effects in an urban water balance model. Journal of the American Water Resources Association 44. (1): 75-84. Doi: 10.1111/j.1752-1688.2007.00139.x

Wilby, R.L. 2019. A global hydrology research agenda fit for the 2030s. Hydrology Research 50. (6): 1464-1480. Doi: 10.2166/nh.2019.100

Xiao, Q. and McPherson, E.G. 2002. Rainfall interception by Santa Monica's municipal urban forest. Urban Ecosystems 6. 291-302. Doi: 10.1023/B:UE CO.0000004828.05143.67

Zhang, N., Luo, Y.J., Chen, X.Y., Li, Q., Jing, Y.C., WANG, X. and FENG, C.H. 2018. Understanding the effects of composition and configuration of land covers on surface runoff in a highly urbanised area. Ecological Engineering 125. 11-25. Doi: 10.1016/j. ecoleng.2018.10.008

\section{Other sources:}

Hirabayashi, S. and Endreny, T.A. 2016. Surface and Upper Weather Pre-processor for i-Tree Eco and Hydro. Manuscript, 1-19. Available at https://www.itreetools.org/documents/52/Surface_weather_and_upper_air_preprocessor_description.pdf

i-Tree 2016. $i$-Tree Hydro User's Manual v5.1. Available at https://www.itreetools.org/documents/241/ Hydro_Manual_v5.1.pdf 